\title{
Rhetorical Structure of Superstitious Images in Coleridge's The Rime of the Ancient Mariner
}

\author{
Rufaidah Kamal Abdulmajeed ${ }^{1}$ \\ ${ }^{1}$ English Department, College of Education for Women, University of Baghdad, Iraq \\ Correspondence: Rufaidah Kamal Abdulmajeed, English Department, College of Education for Women, \\ University of Baghdad, Baghdad, Al-Jadiriyah Compound, Iraq. E-mail: hajeya2@gmail.com
}

Received: April 10, 2017 Accepted: April 24, 2017 Online Published: July 15, 2017

doi:10.5539/ijel.v7n4p138 URL: http://doi.org/10.5539/ijel.v7n4p138

\begin{abstract}
The Rime of the Ancient Mariner by Samuel Taylor Coleridge was written in a way to inspire fear and create a somber, dark and terrifying atmosphere to attract the readers' attention and to steer the attention of the readers to the themes of supernatural events and deep superstitions, thus highlighting these salient themes.

The main aim of this study is to highlight the superstitious images in The Rime of the Ancient Mariner and analyse them according to Hoey's (1983) Problem-Solution Pattern of rhetorical structure of discourse analysis by showing how certain lexical items can signal the narrative structure of the whole texts. The discourse analysis of the stanzas that carry superstitious images shows that this theory is applicable not only to sentences but to poems as well. Stanzas as grammatical units with complete thoughts can be analysed as well since they have the same narrative structure. The results show that all the stanzas, the subject of the analysis, have the rhetorical narrative structure components. They are namely; situation, problem, response, evaluation whether positive or negative.
\end{abstract}

Keywords: Superstition, discourse analysis, rhetorical structure, linguistics, Coleridge's The Rime of the Ancient Mariner

\section{Introduction}

The Romantic poets were very interested in imagination and they made use of all aspects of life that arouse the imagination including gothic elements of horror and fear and suspense. The early Romantics believed in this idea and it is found everywhere in the poems of Wordsworth and Coleridge, but not so much in the poems of the late Romantics.

Although The Rime of the Ancient Mariner has gothic elements, they are used to highlight the moral of the story. The moral stresses the idea that loving God's creatures in the world of nature is the way to salvation.

In The Rime of the Ancient Mariner, Coleridge shows non-human images to inspire fear and even horror in the readers. He argues in this poem that bad deeds and guilt should be followed by justice. In the poem, guilt and justice are represented by supernatural phenomena and superstitious images.

Coleridge's poem reflects many themes from a spiritual perspective: the greater power of the physical or natural world and the theme of crime and punishment. These themes and images are presented through two realms, the realm of reason and the realm of imagination.

One of the most superstitious and terror-inspiring images is the story of the Albatross. Coleridge gives an image of horror when he tells the story of the Ancient Mariner who, by killing the albatross, brings a curse upon himself. Vividly he describes how instead of the cross which represents the Christian faith, the albatross hang round the Mariner's neck:

Ah! well a-day! what evil looks

Had I from old and young!

Instead of the cross, the Albatross

About my neck was hung.

Coleridge introduces and highlights the themes of guilt and repentance as a kind of psychological treatment. 
Thus in the following stanzas, he portrays the Mariner going through a time of agonizing penance and consequently turning into a person who is so kind with all other creatures around him as a means of repentance for his guilt. These creatures like those colourful snakes rouse in him sudden tender feelings and only then does his guardian angel pities and takes care of him. The spell begins to break and the Albatross fell from his neck and fell into the sea like some heavy lead.

\section{Superstition}

Superstition is defined as a kind of beliefs that can be described as illogical interpretations of some events and of some laws of nature.

Bonnerjea (1927, p. 3) defines superstition subjectively as "the disposition or tendency to ascribe phenomena which admit of natural explanation to occult or supernatural causes" and objectively "it is any system of religious belief or practice which manifests such a tendency."

Superstition is an unreasonable belief in things or phenomena owing their origin to natural and to some supernatural force or power, and which are ill interpreted by people.

Bonnerjea (ibid, p. 2) states that superstition is a well-known fact spreading among primitive people; the more advanced people are the less superstitious they become. He further concentrates on the fact that the environment is the most crucial factor in making superstitions:

the moment anything can be logically answered, superstition comes to an end; but as long as we cannot understand the causes and effects, we are groping in the dark, and our imagination is given full play. It is also a well-known fact that advancement influences our imagination to a very great extent. There are several very important factors in the making of superstitions, the foremost of which is our environment.

He gives an example of a villager living his primitive life and a town-bred college man. The imagination of the former is much richer than the imagination of the latter, consequently, the villager believes in superstitions more than the city man because imagination is the seed of superstition when it is combined with ignorance (ibid.).

Pandey (2009, p. 229) considers these superstitious principles are nothing but "baseless assumptions" and "a kind of false science" that lead to a fallacious guide of conduct. This is so because the idea of science does not exist in the undeveloped mind of the believers of those superstitions. Therefore, these beliefs are denounced by the developed-minded nations.

Those who perform and believe in these baseless assumptions lack scientific knowledge, thus making a connection between natural phenomena and their practical outcome.

\section{Coleridge and the Rime of the Ancient Mariner}

Samuel Taylor Coleridge is one of romantic poets. He was born in 1772 in Devonshire, England, and conducted a very disquiet life due to "his own sensitive and uneven temperament". He was described as "Logician, Metaphysician, Bard" (Paul, 2007, p. 1). His parents showed a great affection to him but he resented his family care and sought escape in reading tales of adventure and romance. Introspective as he was, he sought refuge in books of various writers and later he became interested in Medicine and Metaphysics. He left Cambridge in 1794 without taking a degree and had settled in a cottage at Clevedon in Somerset and pursued his literary writing. He wrote a few poems and published his first collection of his verse under the title Poems on Various Subjects.

In the company of Wordsworth, his old friend and a great English poet at that time, Coleridge found the mental peace, security and environmental harmony. It provided him with warmth and affection. This resulted in the sudden release of his creative impulse leading to the composition of The Ancient Mariner.

His reputation as a poet rests on four to five poems composed within a short period of six years. His poems can be divided into: personal poems, political poems and romantic poems. His reputation as a romantic poet rests on three of his romantic poems: The Rime of the Ancient Mariner, Kubla Khan and Christabel (ibid, p. 11).

Though he is a romantic poet but the essence of Coleridge's romanticism lies in his artistic treatment of the supernatural. In his poetry, he puts a place for bold adventure, the joy of discovery as well for romantic stories which differentiate him from other romantic poets whose poetry is dominant by romantic actions. One of these miscellaneous topics is the artistic treatment of superstitions or as called by some authors, the supernatural.

The Rime of the Ancient Mariner, the subject of this study, is the only long poem he completed:

it is written in a modified form of the ballad stanza and is memorable for its skilful unity, vivid phrases and "shadows of imagination" made real. A simple tale of crime and punishment, it embodies the central though that the real prayer of God consists in the love of God's creation (ibid). 
What attract contemporary readers first was "the strangeness of its style, its innovative and liberal use of obsolete words, archaic spellings, and sometimes awkward syntactic inversions" (Hill, 1983, p. 110).

It was written in ballad-stanza, a four-line stanza in which the first and the third lines are in iambic tetrameter, while the second and fourth lines have rhyme and are in iambic trimester. Alliteration is abundant and so is repetition, both simple and incremental, in which a line or stanza is repeated with some small but material substitution (ibid, p. 138).

\section{Superstition in The Rime of the Ancient Mariner}

Coleridge's three most important poems, The Rime of the Ancient Mariner, Kubla Khan and Christabel, are mainly concerned with supernaturalism and superstitions.

Supernatural and superstition are used in The Rime of the Ancient Mariner to create a dark atmosphere of horror and to highlight the main themes of the poem which are: man can do wrong things and commit errors but he can be forgiven if and only if he repents; and to convey a message that guilt and justice follow those who act wrongly. Guilt and justice are represented throughout presenting unnatural phenomena. The description of weather in the poem gives the readers feelings of unrest and makes them uncomfortable. All these contribute to the dramatic theme of the poem and attract the reader's and the listener's attention.

The Rime of the Ancient Mariner is one of the poems that was first intended to be a simple imitation of the Gothic horror-ballad made popular at that time but it was expanded and heavily revised in order to exemplify the aesthetic theory of the supernatural.

It is worth mentioning that supernatural poems belong to the poetic imagination of the poet and are open to historical interpretation. Newlyn (2002, p. 10)

"The Ancient Mariner", although not explicitly a political poem, arose from Coleridge's radical opposition to slavery, and it makes his readers aware of their fatal attraction to the powerful, makes them "share the terror, desperation, and desire of a man enslaved, in mind and body" (ibid).

while Fulford (2002, p. 47) considers Coleridge as a psychologist. He suggested that "curses work when the cursed person is guilty enough to allow them to." But Coleridge employed the supernatural as "an expressive medium, or symbol, for "romantic" emotional states (fear, guilt, remorse, etc.) and to imitate these states with such psychological fidelity and dramatic force" (Hill, 1983, p. 129).

One of the most prominent features of The Rime of the Ancient Mariner is superstition. Coleridge's Polar Spirit is one of his well-known characters. He graphed the horror of a nightmare in the figure of "Life-in-Death". These figures were inspired by the literary horror-ballads of the eighteenth century.

Fulord, (2002, p. 49) says that in The Rime of the Ancient Mariner,

a sea voyage into unknown areas forms an outward dramatisation of the inward conditions that, in Coleridge's diagnosis, produced superstition. The mariner journeys beyond the limits of geographic knowledge, where he finds himself helpless before powers and events over which he has no control.

The Mariner finds himself helpless and powerless the more he penetrates in the ocean just like "a slave before his Lord" (419). He finds himself controlled by powers and forces he cannot understand or even resist. This leads him to believe in the supernatural power of the forces that have control over him. Coleridge's "achievement in "The Rime of the Ancient Mariner" was to take the popular narrative of exploration and to make it an articulation of mental as well as physical voyaging" (ibid).

The superstitious images that appear in the poem are: the "phantom ship with its ghastly crew Death and Life-in Death, the Polar Spirit seeking vengeance for the murder of the Albatross, two supernatural voices representing justice and mercy, and a troop of celestial spirits animating the dead crew" (Paul, 2007, p. 18).

The present study will deal with the Albatross killing and the animation of the dead crew of the ship.

\section{The Linguistic Theory of the Analysis}

The analysis of the superstitious images in The Rime of the Ancient Mariner will be carried out by the application of the linguistic theory proposed by Hoey (1983) called "Problem-Solution Pattern". By Pattern, he means combination of relations organizing (part of) a discourse which can be revealed by paraphrase and questions (Hoey, 1983, p. 31).

Hoey (1979, 1983, 1986, 1993 and 1994) proposes a noteworthy thesis and a new model for discourse analysis in terms of rhetorical relations. The problem-solution pattern is considered as a typical way to treat discourse fruitfully. He (1983, p. 33) says that in this model "the emphasis is placed on the ways in which the surface of 
the discourse (not necessarily to be contrasted with hidden depths) contains sufficient clues for the reader/listener to perceive accurately the discourse's organization."

He feels the importance of the study of discourse analysis. He (1983, p. 1) adds that:

In writing, sentences bunch into conventional unites called paragraphs, paragraphs into chapters, and chapters into books. In short, in our everyday speech and writing, the sentence is only a small cog in a normally much larger machine. It is the task of discourse analysis to find out how that machine works, partly because it is fascinating in itself, and partly because at times particular machines need repairing.

Hoey (ibid, p. 5) feels that the native speakers have the ability and are innately capable of "a considerable degree of discourse reconstruction" (ibid, p. 5). He reaches this conclusion after giving a group of his students badly ordered sentences and ask them to reorganize these sentences in a new well organized text. These results showed that the students had an instinctive knowledge of discourse and had the ability to discern the patterns of organization of discourse.

Hoey (1983, pp. 32-34) proposes "a starting assumption", before beginning with the examination of the means of the analysis. These assumptions are divided into groups. The following two assumptions are concerned with the organization of discourse:

1) "Discourse and passages of discourse are organized,"

2) "they are organized at least in part in a hierarchical manner."

The next two assumptions are concerned with the way the discourse is perceived:

1) "the native speaker can assess whether a sentence is grammatical,"

2) "he can assess also whether a discourse is well-formed."

These assumptions suggest the ability among native speakers to perceive discourse organization.

One more assumption is also made by Hoey that:

1) "there is something in the discourse itself that helps the listener or speaker to perceive the structure," by means of clues appearing on the surface of the discourse which help reader/listener "to perceive accurately the discourse organization."

The third group of assumptions consists of:

1) "If discourses do contain clues as to their organization, it is possible that it is the clues that are finite and not the patterns of organization they point to." It means that an indefinite number of patterns can be built out of these limited patterns.

2) "at the lower levels of discourse, that is, those commonly associated with the paragraph, there are indeed also a finite number of possible relations.

This brief introduction of Hoey's theory of discourse analysis necessitates another introduction for the difference between the sentences of the text which is the substance of Hoey's analysis and the stanza of the poem which is the substance of the analysis in this study.

Stanza is the main unit of the poem. It is how the poem arranged in a group of ordered lines. It is either written in two lines (couplets) and or in four lines (quatrains). The break between each stanza means that a poem will change its topic and starts a new emphasis or it is a kind of pause in the progression.

This kind of arrangement of lines is called a unit. A unit of poetic lines is equal to a paragraph separated by blank lines. The lines of each stanza are not in the same length and meter. This kind of stanza created in such irregular lines is often dictated by meaning as in a prose paragraph (Poetic devices: on-line).

Hoey (1983, p. 34) substitutes the word "discourse" for "sentence" and "discourse analysis" for "immediate constituents", therefore, "discourse, like sentences, can be analysed in terms of multiple layers, each layer providing details about the unanalyzed units of the layer above" (ibid). Furthermore, he (ibid, p. 18) substitutes the word "relations" for the term "clause relations." He says:

A relation involves the addition of something; when two pieces of language are placed together, if their meaning together is more than the sum total of their separate parts, then they are in relation with each other. If on the other hand no meaning is added when they are placed together, or if no agreement can be reached about the meaning that might have been added, then they are not in a relation with each other (ibid, p. 7).

This means that stanzas can, in relation with each other, form a unit of meaning the same as sentences do. The 
substitution of stanza for a sentence as unit of grammar means that a stanza can be considered a full sentence which has a complete thought. This result proves that this theory is highly applicable to the analysis of this poem.

Hoey (1979, p. 33) identifies two ways to locate the presence of a rhetorical pattern. The first is by projecting the discourse into a dialogue involving questions and answers. To explicate this method, he (1986, p. 191) proposes the following example:

(1) Charles was a language teacher. (2) His students came to him unable to write coherently. (3) He taught them discourse analysis. (4) Now they all write novels.

Projecting this text into a dialogue, the result can be as follows:

1) $\quad \mathrm{D}$ (iscourse): Charles was a language teacher

Q(uestion): What problem arose for him?

2) D: His students came to him unable to write coherently.

Q: What did he do about it?

3) D: He taught them discourse analysis.

Q: What was the result?

4) D: Now they all write novels.

Such interrogative method helps establish the relationships between the sentences in the text. Thus, in Hoey's text, sentence (1) can be identified as the situation, sentence (2) as the problem, sentence (3) as the solution, and sentence (4) as the positive evaluation.

The second method of identifying patterns in the text is by means of lexical items that are found within the body of the discourse itself. The text could be rewritten as follows:

(1) Charles was a language teacher. (2) His students came to him unable to write coherently. (3) His way of dealing with this problem was to teach them discourse analysis, with the result that (4) Now they all write novels.

In the above, way is a two-way signal: it signals that what follows is a solution and what proceeds is a problem. Similarly, the result is a two-way signal indicating that what follows, i.e., sentence 4 , is the result, and that what proceeds, i.e., sentence 3 , is the solution. The emerging pattern could be illustrated graphically in the diagram below:

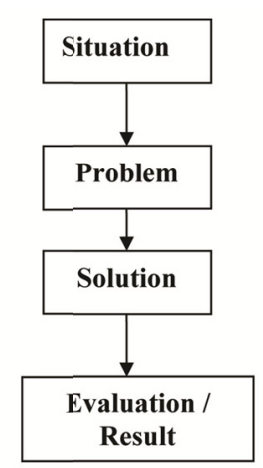

Figure 1. The rhetorical pattern of Hoey's text (1979)

But his (1979)'s model may fall short of analyzing complex texts. Therefore, in his model of (1983), he modifies this pattern by considering evaluation as either positive or negative. Figure (1) shows the positive evaluation, but if the evaluation is negative, it signals another problem that leads to another evaluation as in figure (2): 


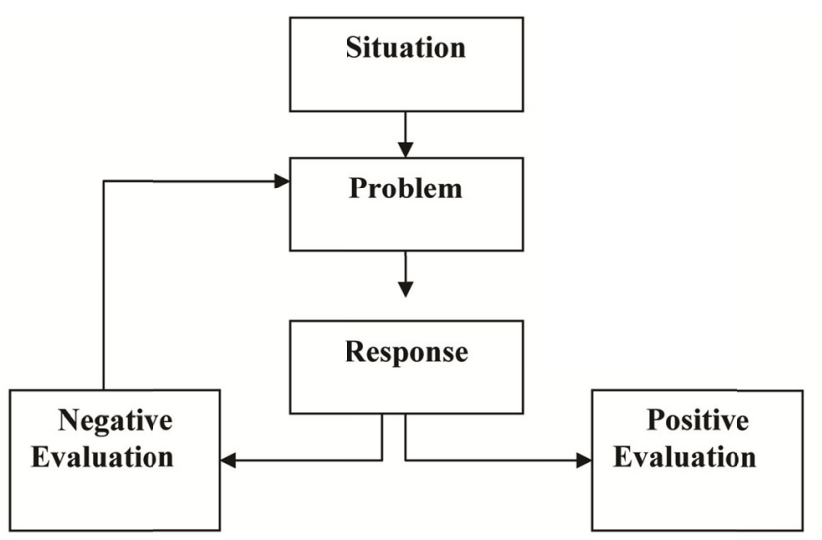

Figure 2. The problem-solution pattern with negative evaluation

\section{The Model of the Analysis}

The researcher will follow Hoey's (1983) model of the Problem-Solution pattern to find out the rhetorical and the narrative structure of the poem's stanzas. The researcher will investigate how each superstitious image in the poem is organized in a rhetorical pattern to show the narrative structure, namely; situation, problem, response and evaluation.

The analysis will be carried out by recognizing the lexical signals that are related to each layer. These lexical signals offer helpful interpretive clues when analyzing each layer. Throughout the recognition of these clues, the relations will be discussed to uncover the discourse structure.

\section{Data}

\subsection{Stanza 1: The Superstitious Image of the Weather}

Part I: lines: 41- 44

"And now the Storm-blast came, and he

Was tyrannous and strong:

He struck with his o'ertaking wings,

And chased us south along.

\section{Paraphrasing:}

A furious storm blast overtook them. It struck the ship with all its wild force and drove the ship to the south (Paul, 2007, p. 41).

\section{Situation:}

The situation is determined by the lexical signals "storm-blast" and "chased". These words give an image of a ship in the sea and a sudden strong storm blast drives them towards the South Pole.

\section{Problem:}

The problem is determined by the lexical signals "tyrannous", "strong", "struck", and "wing". The image in these lines is that the wind is so strong and ferocious to the extent that it takes them away as if flying on wings of a bird.

\section{Response:}

The mariner and the crew are restless all the way and are haunted by fear of destruction of their ship by this strong wind. The response is determined by the lexical signal "us". This refers to the fact that the crew is panic and expecting a punishment for this bad dead.

\section{Evaluation:}

The mariner and his colleges are afraid of death because of this strong wind. The lexical signals "struck", "overtaking", "wings" and "chased" are indicators of negative evaluation.

\section{Superstitious Image:}

The personification of the wind is done by using an animate pronoun "he" to refer to the wind and the word 
"wings" is also used to complete the image of a strong man with wings. Because this furious "man" appears with "his wings" by which "he" struck the ship, the result is that they are driven to the South Pole. The superstitious image here appears in this illogical interpretation of the storm event and of this law of nature which connected superstitiously with an illogical outcome, namely; because the wind comes, we are driven to the South Pole.

\subsection{Stanza 2: The Superstitious Image Is the Albatross}

\section{Part 1: lines 63- 82}

At length did cross an Albatross,

Thorough the fog it came;

As if it had been a Christian soul,

We hailed it in God's name.

It ate the food it ne'er had eat,

And round and round it flew.

The ice did split with a thunder-fit;

The helmsman steered us through!

And a good south wind sprung up behind;

The Albatross did follow,

And every day, for food or play,

Came to the mariner's hollo!

God save thee, ancient Mariner!

From the fiends, that plague thee thus!-

Why look'st thou so?-With my cross-bow

I shot the ALBATROSS.

\section{Part II: lines 91-96}

And I had done a hellish thing,

And it would work'em woe:

For all averred, I had killed the bird

That made the breeze to blow.

Ah wretch! said they, the bird to slay,

That made the breeze to blow!

\section{Paraphrasing:}

At last an Albatross appeared through the fog. The sailors warmly greeted it as if it were a Christian soul. It ate the food the sailors gave and flew round the ship. The ice split with sound like thunder and the helmsman steered the ship through the crack it produced. The nice south wind began and Albatross still followed the ship. It responded to the sailors' call either to take food from their hand or to play with them. It came every day and sat on the mast. This continued for nine days. The Wedding-Guest prayed to God to have mercy on the Ancient Mariner and protect him from devils that tortured him in that manner because the ancient mariner looked horror-stricken. The Wedding-Guest asked him why he looked thus. The Mariner simply replied "I shot the Albatross with my cross-bow." All the shipmates of the Ancient Mariner condemned his action of killing the Albatross. They say that he had done a devilish thing and would bring them misfortune. They said that he had killed the bird of good omen who had caused the favourable wind blow. They declared the Mariner a wretched being for having killed the Albatross (Paul, 2007, p. 43).

\section{Situation:}

The situation is determined by the lexical signals "Albatross", "fog", "came", "hailed", "good", "south", "wind", and "sprung up". The ancient Mariner and his mates are on board of ship and at last an Albatross comes through the snow-fog. It is a pious bird, thus they consider it as if it were a Christian soul. They are very happy with it and they feed it. They receive it with a great joy and hospitality. The Albatross proves that it is of good omen. It follows the ship and it brings a good south wind. 


\section{Problem:}

The problem is determined by the lexical items "shot", "cross", and "bow". The Ancient Mariner shoots the pious bird of good omen who brings good wind.

\section{Response:}

The response is determined by the lexical signals "hellish", and "woe". The shipmates of the Ancient Mariner cry against him for killing the bird of good luck who causes the favourable wind to blow.

\section{Evaluation:}

It is a negative evaluation. The Ancient Mariner says that he has done a hellish thing which would bring misfortune. The sailors condemn the Ancient Mariner's ill-behaviour by killing the pious bird who brings good omen and who represents a figure of salvation (Christ). He follows the ship for nine days, guides them through ice and make them happy during this period. Killing the bird would bring them misfortune.

\section{Superstitious Image:}

It is a sort of burden that he would feel all along his life. The sailors imagine that all bad omens come to them when the Mariner kills the Albatross. They blame him for this devilish deed. They consider that the bird brings a favourable wind but now, when he has gone all good luck has gone too. They declare that the Mariner is a wretched for having killed the Albatross. Shooting Albatross brings curse, woe and bad luck.

\subsection{Stanza 3: The Superstitious Image of the Benefit of Killing Albatross}

\section{Part II: lines 97-106}

Nor dim nor red, like God's own head,

The glorious Sun uprist:

Then all averred, I had killed the bird

That brought the fog and mist.

Twas right, said they, such birds to slay,

That bring the fog and mist.

The fair breeze blew, the white foam flew,

The furrow followed free;

We were the first that ever burst

Into that silent sea.

\section{Paraphrasing:}

The shipmates, then, felt that killing Albatross brought good luck when they saw the fog is cleared off and the bright sun rose, neither dim nor red, but luminous and glorious like the haloed head of Jesus Christ. They felt that killing the Albatross was a right deed. The Mariner was right by killing the bird that had brought fog and mist. Now a favourable gentle wind blew and the white foam flew off from the surface of the ocean. Thus, the ship sailed onward calmly and the track made by it was clearly visible. It seemed that they were the first people who had ever come to this silent sea (Paul, 2007, p. 45).

\section{Situation:}

The situation is determined by the lexical items "glorious sun", "purist", "fair", "breeze", "blow" and "silent sea". The ship continues its sailing in that silent sea as if they were the first who come to this silent sea. The sun rises and the breeze blows.

\section{The Problem:}

The problem is that the sailors agree on the Mariner's action. It is determined by the words "killed", "slay", "right" "fog", and "mist". The sailors declar that the Mariner does the right thing by killing the bird that brings mist and fog. Now it is sunny and faire breeze blows because the bird is not around.

\section{Response:}

The response is determined by the words "Twas right", "fair breeze", "white", "foam", and "flew". The sailors are happy with the killing of the bird. They think that it brings fog and mist and when it is killed, the sun rises neither dim nor red and faire breeze blows. 


\section{Evaluation:}

Their happiness with what the Mariner does give a positive evaluation. They are happy with the death of the bird because they think that Albatross guides them through fog and ice, brings misfortune to them and leads the ship to the icy sea.

\section{Superstitious Image:}

The sailors think that Albatross' sitting on the mast of the ship and sailing round the ship brings a bad omen and makes the moon shine dimly and brings fog and mist. After shooting it, the sun rises, the ship sails calmly and the gentle wind blows. They agree with the Mariner that killing the bird clears off the mist and fog and makes a soft breeze blows again and thus make themselves accomplices in the crime.

The relation between the death of the bird on one hand, and the clearance of the fog and mist, the shining of the sun, the faire breezing of the wind and the calmness of the sea, on the other hand shapes the superstitious image.

\subsection{Stanza 4: The Superstitious Image Life-in-Death}

\section{Part III: lines 185-194}

Are those her ribs through which the Sun

Did peer, as through a grate?

And is that Woman all her crew?

Is that a DEATH? and are there two?

Is DEATH that woman's mate?

Her lips were red, her looks were free,

Her locks were yellow as gold:

Her skin was as white as leprosy,

The Night-mare LIFE-IN-DEATH was she,

Who thicks man's blood with cold.

\section{Paraphrasing:}

A mysterious thing appeared and stood between the sun and their ship. They prayed to Virgin Mary to have mercy on them. Then a skeleton ship appeared and approached them. The Ancient Mariner looked with horror at the ribs of the ship as they looked as the bars of a prison and the sun behind them looked like a prisoner peeping behind these iron bars. He saw just one woman on the ship and wondered if she was the only crew. Then he noticed another figure. The first figure looked like the spirit of death. He wondered if the second figure was her mate.

The woman's lips were red, her hair was golden yellow and she had very bold looks. That horrible woman with white skin was Life-in-Death. She was a nightmare personified and was capable of horrifying any man and curdling his blood (Paul, 2007, p. 49).

\section{Situation:}

The situation is highlighted by the lexical signals "ribs", "sun", "crew", and "mate". The ship is in the sea and another ship comes nearer to the first one. The crew of the first ship is horrified because they do not know who are on the other one. Suddenly a woman appears as the crew of this new ship. Because of the reflection of sun on the ribs of the ship, these are seen as bars of a prison on the face of the setting sun.

\section{Problem:}

The problem is signaled by the lexical items "death", "crew", "woman", and "mate". The sailors think that the ribs of the ship that is approaching them and becoming nearer to them are prison bars and that woman, the only crew of the ship, is a prisoner behind these bars. They wonder who that woman is. Is she a death mate of life?

\section{Response:}

The scene is as a nightmare that terrifies them and is capable of curdling any man's blood. The sailors imagine that woman as life accompanied with her mate, death. The ghostly figure here is Death-in-life, a figure that crystallized the deadly torture of the Mariner and the sailors, which is different from the idea of "life accompanied by death". The Ancient Mariner describes this woman with red lips and golden hair. Her white skin is just like a person with leprosy. This horrible scene terrified the sailors. It is an image of life-in-death. 


\section{Evaluation:}

The evaluation is negative. Life is resembled to a woman that walks hand in hand with death; it means life is haunted by death.

\section{The Superstitious Image:}

The ribs of the ship are seen as prison bars and the reflection of the sun on these bars makes a shadow of a woman as a ghost standing behind these bars. The superstitious image here is the shadow of the woman. The Mariner first sees just one woman on the ship which represents life and suddenly notices another figure, her shadow, which he thinks that it is the spirit of death. This counter image or the shadow of the woman means that life is haunted by death and they walk hand by hand.

\section{Results and Discussion}

The analysis of the stanzas of The Rime of the Ancient Mariner which have superstitious images shows that these stanzas are organized as relation networks rather than primarily hierarchical. Hoey, in his model, emphasizes the fact that, any sentence (or part of a sentence or group of sentences) may be in relation with any other sentence within the same discourse. The same is with the stanzas. They are organized in a way that their relation to each other is clearly obvious.

The assumptions of Hoey (1983, pp. 32-34) are also found in the construction of the stanzas of The Ancient Mariner. They are organized in a hierarchical manner; the native speaker or the reader can assess that these stanzas are well-formed grammatically; the lexical signals and clues help the reader to perceive the structure and the accurate discourse organization; these clues are finite and not the pattern of organization they point to. Indefinite number of patterns can be built on these limited patterns; and finally, there are a finite number of possible relations.

The result of the analysis shows that The Problem-Solution model is highly applicable to such kind of narrative stanzas. The layers, namely, situation, problem, response and evaluation, whether positive or negative, are found during the process of the analysis. All the stanzas that are selected from the poem to be the data of the analysis show these layers very clearly.

\section{Conclusion}

Hoey's model of discourse analysis is initiated to analyze a text that contains grammatical sentences. This study reveals that this model can be applicable to literary works and specifically to poetry. The application of The Problem-Solution pattern to find the rhetorical structure of Coleridge's The Rime of the Ancient Mariner shows that this narrative poem has a narrative structure and Hoey's model fits the analysis of superstitious images in this poem. In other words, it has all the components of this rhetorical pattern: the situation whose function is providing enough background information for the reader to understand the problem being presented. It provides the reader an indication of the setting before moving to the problem; the problem could be an action, a dilemma, a question or an obstacle. Such signals are revealed clearly in the structure of the stanzas; the response is represented by any action that is produced as a reaction towards finding the solution to that problem. It represents the kind of improvement being introduced for the purpose of solving the problem identified in the text; finally, the concept of evaluation implies the kind of information being presented about something that tells us how good or bad that thing is. It consists of an assessment. Some stanzas have positive evaluation and others have negative evaluation.

It is concluded that poems are composed of rhetorical structure and all the aforementioned components are available in the stanzas of the poem. It also is concluded that the problem-solution pattern can be applied on the grammatical sentences as well as on the stanzas of the narrative poems.

\section{References}

Bonnerjea, B. (1927). A Dictionary of Superstitions and Mythology. London: Folk Press Limited.

Fulord, T. (2002). Slavery and superstition in the supernatural poems. In L. Newlyn (Ed.), The Cambridge Companion to Coleridge. Cambridge: Cambridge University Press. https://doi.org/10.1017/CCOL0521650712.004 Hill, $\begin{aligned} & \text { J. } \\ & \text { https://doi.org/10.1007/978-1-349-03798-8 }\end{aligned}$

Hoey, M. (1979). Signaling in Discourse. Birmingham: University of Birmingham.

Hoey, M. (1983). On the Surface of Discourse. London: George, Allen and Unwin. 
Hoey, M. (1986). Overlapping Patterns of Discourse Organization and their Implications for Clause Relational Analysis of Problem-Solution Text. In C. R. Cooper \& S. Greenbaum (Eds.), Studying Writing: Linguistic Approaches. London: Sage Publications.

Hoey, M. (1991). Patterns of Lexis in Text. Oxford: Oxford University Press.

Hoey, M. (1993). A Common Signal in Discourse: How the Word Reason is Used in Texts. In J. M. Sinclair, M. Hoey, \& G. Fox (Eds.), Techniques of Description: Spoken and Written Discourse. London: Routledge and Kegan Paul.

Hoey, M. (1994). Signaling in Discourse: a Functional Analysis of a Common Discourse Pattern in Written and Spoken English. In M. Coulthard (Ed.), Advances in Written Text Analysis. London: Routledge.

Newlyn, L. (2002). Introduction. In L. Newlyn (Ed.), The Cambridge Companion to Coleridge. Cambridge: Cambridge University Press. https://doi.org/10.1017/CCOL0521650712.001

Pandey, K. C. (2009). Religious Beliefs, Superstitions and Wittgenstein. New Delhi: Readworthy Publications Ltd.

Poetic Devices. Retrieved from http://www.chaparralpoets.org/devices.pdf

Rajinder, P. (2007). S.T. Coleridge: An Evaluation of his Poetry. New Delhi: Rama Brothers.

\section{Copyrights}

Copyright for this article is retained by the author(s), with first publication rights granted to the journal.

This is an open-access article distributed under the terms and conditions of the Creative Commons Attribution license (http://creativecommons.org/licenses/by/4.0/). 